\title{
PENINGKATAN HASIL BELAJAR IPA SISWA KELAS V MELALUI METODE RESITASI DI SD AL AZHAR SYIFA BUDI JAKARTA SELATAN
}

\author{
Harlinda Syofyan \\ Universitas Esa Unggul \\ soflynda@yahoo.com\
}

\begin{abstract}
The purpose of the study is to obtain empirical data about the result of learning science held at SD Al Azhar Syifa Budi Jakarta Selatan, on the subject of "Living things Adaptation with Environment". This study uses action research, which emphasizes the teaching of Science by using the method of recitation. The subjects are students at SD Al Azhar Syifa Budi Jakarta Selatan totaling 22 people. Other participants are the main researcher and two colleagues observer of the elements in the same school. Data collection technicques used in this study is through tests (daily tests) and the result observation.This result of the study shows that the achievement of minimum competence criteria in learning (Mastery Learning) held on the second cycle of $90,90 \%$. This study conclude : 1) Recitation teaching methods can improve learning outcomes on science on competences basis "Living things Adaptation with Environment"., and 2) There is a relation between the student's achievement with the learning of operational steps, which are designed in a classroom action research conducted by researcher.
\end{abstract}

Key words: recitation methode, result of science, adaptation of living things

\begin{abstract}
Abstrak: Tujuan dari penelitian ini adalah untuk memperoleh data empiris tentang hasil belajar ilmu diadakan di SD Al Azhar Syifa Budi Jakarta Selatan, pada subjek "Hidup hal Adaptasi dengan Lingkungan". Penelitian ini menggunakan penelitian tindakan, yang menekankan pengajaran Ilmu dengan menggunakan metode pelajaran recitation. The adalah mahasiswa di SD Al Azhar Syifa Budi Jakarta Selatan berjumlah 22 orang. Peserta lainnya adalah peneliti utama dan dua rekannya pengamat dari unsur-unsur di sekolah yang sama. technicques pengumpulan data yang digunakan dalam penelitian ini adalah melalui tes (tes harian) dan hasilnya hasilnya observation. This penelitian menunjukkan bahwa pencapaian kriteria kompetensi minimum dalam belajar (Mastery Learning) yang diselenggarakan pada siklus kedua 90,90\%. Penelitian ini menyimpulkan: 1) metode pengajaran Zikir dapat meningkatkan hasil belajar ilmu pengetahuan tentang kompetensi dasar "Hidup hal Adaptasi dengan Lingkungan", dan 2) Ada hubungan antara prestasi siswa dengan belajar dari langkah-langkah operasional, yang dirancang dalam. penelitian tindakan kelas yang dilakukan oleh peneliti.
\end{abstract}

Kata kunci: metode pembacaan, hasil dari ilmu pengetahuan, adaptasi makhluk hidup

Penggunaan metode pembelajaran yang tepat, merupakan suatu alternatif mengatasi masalah rendahnya daya serap siswa terhadap pelajaran IPA, guna meningkatkan mutu pengajaran. Penerapan suatu metode pengajaran harus ditinjau dari segi keefektifan, keefesienan dan kecocokannya dengan karakteristik materi pelajaran serta keadaan siswa yang meliputi kemampuan, kecepatan belajar, minat, waktu yang dimiliki dan keadaan sosial ekonomi siswa sebagai objek. 
Peningkatan Hasil Belajar Ipa Siswa Kelas V Melalui Metode Resitasi Di Sd Al Azhar Syifa Budi Jakarta Selatan

Herlynda Syopyan

IPA adalah salah satu mata pelajaran yang diberikan di Sekolah Dasar. Pendidikan IPA pada tingkat dasar akan memberikan kontribusi yang sangat berarti bagi keseluruhan proses pendidikan anak dan perkembangan individu selanjutnya. IPA memberikan pengetahuan tentang lingkungan alam, mengembangkan keterampilan, wawasan, sebagai sarana yang penting untuk penguasaan IPTEK dan penanaman nilai-nilai serta sikap dalam menghargai alam dalam hubungannya dengan kehidupan manusia, sehingga memiliki kesadaran teknologi dalam kaitannya dengan pemanfaatan bagi kehidupan sehari-hari. Oleh karena itu pada pembelajaran IPA, guru hendaknya mengajar dengan cara melibatkan siswa secara aktif dalam proses pembelajaran..

Salah satu metode yang diterapkan dalam melibatkan siswa secara aktif, guna menunjang kelancaran proses belajar mengajar adalah menggunakan metode resitasi. Dalam metode resitasi diharapkan mampu memancing keaktifan siswa dalam proses belajar mengajar. Hal ini disebabkan karena siswa dituntut untuk menyelesaikan tugas yang diberikan guru dan harus dipertanggungjawabkan.

Metode pembelajaran yang sesuai dengan materi yang diajarkan akan meningkatkan motivasi belajar siswa. Pemberian tugas pada setiap pertemuan mempengaruhi hasil belajar siswa. Pada peningkatan prestasi belajar siswa bukan hanya peran guru yang dibutuhkan tetapi siswa sendirilah yang dituntut peran aktif dalam proses belajar mengajar. Salah satu hal yang penting dimiliki oleh siswa dalam meningkatkan prestasi belajarnya adalah penguasaan bahan pelajaran. Banyak metode yang dapat digunakan oleh guru dalam upaya mengaktifkan siswa, salah satunya adalah metode resitasi. Metode Resitasi adalah metode pembelajaran dengan penyajian bahan oleh guru dengan cara memberikan tugas tertentu agar siswa aktif dalam pembelajaran dan memberikan bimbingan dalam menyelesaikan tugas serta mengevaluasi siswa dalam mempertanggungjawabkan tugas yang telah diberikan. Selanjutnya diharapkan metode Resitasi ini dapat menjadi solusi yang terbaik untuk mengaktifkan siswa dalam meningkatkan hasil belajar IPA di Al Azhar Syifa Budi Jakarta Selatan.

Menurut Syaodih (2005) Hasil belajar atau achievement merupakan realisasi atau pemekaran dari kecakapan-kecakapan potensial atau kapasitas yang dimiliki seseorang. Penguasaan hasil belajar oleh seseorang dapat dilihat dari perilakunya, baik perilaku dalam bentuk penguasaan pengetahuan, keterampilan berpikir maupun kemampuan motorik. Hampir sebagian terbesar dari kegiatan atau perilaku yang 
diperlihatkan seseorang merupakan hasil belajar. Menurut Syah (2010), hasil belajar adalah cerminan prestasi yang dicapai seorang siswa terhadap suatu program pengajaran tertentu sesuai dengan kriteria yang telah ditetapkan.

Menurut Winkel (1983) hasil belajar merupakan hasil yang telah dicapai melalui pengalaman belajar. Hasil belajar yaitu suatu perubahan yang terjadi pada individu yang belajar, bukan hanya perubahan mengenai pengetahuan, tetapi juga untuk membentuk kecakapan, kebiasaan, pengertian, penguasaan, dan penghargaan dalam diri seseorang yang belajar (dunia baca :2011) Sedangkan Briggs dalam Kusdianti (2010) menyatakan hasil belajar adalah seluruh kecakapan dan segala hal yang diperoleh melalui proses belajar mengajar di sekolah yang dinyatakan dengan angka dan diukur dengan menggunakan tes hasil belajar. Sedangkan Sudjana, (1990) mendefinisikan hasil belajar sebagai kemampuan-kemampuan yang dimiliki siswa setelah ia menerima pengalaman belajar.

Bloom mendefinisikan hasil belajar adalah sebagian munculnya perubahan tingkah laku yang timbulnya tiga ranah kognitif, afektif, dan psikomotor. Ranah kognitif berkenaan dengan tujuan-tujuan pembelajaran dalam kaitannya dengan kemampuan berpikir, mengetahui, dan memecahkan masalah yaitu meliputi: 1) pengetahuan, 2) pemahaman, 3) aplikasi, 4) analisis, 5) sintesis dan 6) evaluasi. Sementara itu menurut Syah (2010), bahwa hasil belajar siswa dapat juga dilihat dari tiga aspek, yaitu (1) aspek kuantitatif, yaitu menekankan pada pengisian dan pengembangan kemampuan kognitif dengan fakta-fakta yang berarti; (2) aspek institusional atau kelembagaan, yaitu menekankan pada ukuran seberapa naik perolehan belajar siswa yang dinyatakan dalam angka-angka; (3) aspek kualitatif, yaitu menekankan pada seberapa baik pemahaman dan penafsiran siswa terhadap lingkungan disekitarnya sehingga dapat memecahkan masalah yang dihadapinya dalam kehidupan sehari-hari.

Dari uraian diatas, yang dimaksud dengan hasil belajar adalah kemampuan yang dimiliki oleh siswa setelah mengalami proses belajar mengajar dan dapat diukur melalui ranah kognitif berupa pengetahuan, pemahaman, aplikasi, analisis, dan sintesis serta evaluasi dan ranah afektif serta psikomotorik yang dicapai siswa dari hasil kegiatan pembelajaran atau merupakan tingkat penguasaan yang dimiliki siswa setelah menerima pengalaman belajar.

Semiawan mengartikan Ilmu Pengetahuan Alam (IPA) mencakup aspek-aspek pengetahuan yang tidak terbatas pada fakta dan konsep saja, tetapi juga aplikasi konsep dan prosesnya yang mengacu pada pemelekan pikir manusia (Semiawan: 1989) dalam proses 
Peningkatan Hasil Belajar Ipa Siswa Kelas V Melalui Metode Resitasi Di Sd Al Azhar Syifa Budi Jakarta Selatan

Herlynda Syopyan

belajar mengajar, tugas guru tidak hanya terbatas memberikan informasi ilmu pengetahuan kepada siswa. Menurut Mariana (1995), tugas yang lebih berat adalah mengusahakan bagaimana konsep-konsep penting dan yang berguna dapat tertanam kuat di dalam benak siswa. Pada pembelajaran IPA, siswa hakikatnya memahami baik proses maupun produknya, oleh karena itu mengajarkan IPA yang terbatas kepada produknya dianggap belum lengkap karena baru mengajarkan salah satu komponennya.

Carin dan Sund (1989) menjelaskan bahwa IPA merupakan suatu cara untuk mengetahui tentang lain melalui kumpulan data yang diperoleh melalui pengamatan dan penelitian yang terkontrol yang didalamnya memuat proses, produk dan sikap manusia. Dengan demikian IPA didasarkan pada pendekatan empirik dengan asumsi bahwa IPA dapat dipahami, dipelajari, dan dijelaskan tidak semata-mata bergantung pada metode kausalitas, tetapi melalui proses tertentu, misalnya observasi, eksperimen, dan analisis rasional. Dalam kaitan ini digunakan juga sikap tertentu, seperti bersikap objektif dan jujur dalam mengumpulkan serta menganalisis data.

Hasil belajar IPA siswa Sekolah Dasar adalah segala perubahan kemampuan yang terjadi pada siswa sekolah dasar yang berkenaan dengan mata pelajaran sains sebagai hasil dari mengikuti proses pembelajaran IPA di Sekolah Dasar. Pencapaian hasil belajar siswa mencakup perubahan kemampuan dalam hal penguasaan konsep IPA, penguasaan proses IPA dan penguasaan sikap IPA. Secara khusus hasil belajar IPA dalam penelitian ini dibatasi pada penguasaan produk IPA dan proses IPA.

Dari uraian di atas maka dapat disimpulkan hasil belajar IPA adalah adalah kesanggupan siswa menguasai pengetahuan keterampilan IPA yang meliputi; mengetahui, memahami, menerapkan,serta menganalis yang mencakup kegiatan belajar mengajar pada materi "Penyesuaian Makhluk Hidup". Pencapaian hasil belajar IPA siswa mencakup perubahan kemampuan dalam hal penguasaan dan proses IPA.

Sanjaya (2006), Pendidikan tidak sematamata berusaha untuk mencapai hasil belajar, akan tetapi bagaimana memperoleh hasil atau proses belajar yang terjadi pada diri siswa. Disinilah pembelajaran menekankan pada proses belajar yakni bagaimana siswa belajar. Pembelajaran harus mampu menghadirkan metode yang mampu membelajarkan siswa. Inovasi dalam metode-metode pembelajaran mempunyai dua aspek yang saling terkait, yaitu aspek keterampilan mengajar dan tata 
cara yang digunakan guru dalam menyusun tugas-tugas untuk siswa.

Menurut Djamarah dan Zain (2006) metode resitasi atau penugasan adalah metode penyajian bahan di mana guru memberikan tugas tertentu agar siswa (dapat diberikan secara individual atau kelompok) melakukan kegiatan belajar dan pada akhirnya mempertanggung jawabkan tugas tersebut. Menurut Joyce, Weil dan Calhoun (2009) berkenaan dengan bagimana guru mengajar sebagai proses penyesuaian diri guru baru terhadap kegiatan mengajar lebih didominasi oleh pola resitasi. Pada dasarnya, pola resitasi dilakukan dengan memberikan tugas kepada siswa, biasanya anak belajar tentang sesuatu, dan kemudian siswa menjawab pertanyaan yang mengungkap penguasaannya. Bahanbahan pelajaran terintegrasi dengan latihan soal-soal. Metode pemberian tugas atau resitasi merupakan metode mengajar yang berupa pemberian tugas oleh guru kepada siswa, dan kemudian siswa harus mempertanggungjawabkan atau melaporkan hasil tugas tersebut.

Menurut Kook (1992) metode pemberian tugas merupakan metode yang sering digunakan untuk melatih mata pelajaran sesudah suatu isi pelajaran dipelajari. Definisi metode resitasi yang dikemukakan di atas memberikan penekanan bahwa secara istilah metode resitasi juga dikenal dengan metode mengajar pemberian tugas. Pola yang terstruktur di dalam pelaksanaan metode resitasi dimulai dengan guru memberikan tugas kepada siswa, siswa mempelajari suatu bahan pelajaran tertentu, dan siswa mempertanggungjawabkan atau melaporkan tugas tersebut.

Menurut Hamalik (2009) ada dua macam tugas yakni tugas-tugas tindakan (action tasks) dan tugas-tugas kognitif (cognitive tasks). Tugas-tugas tindakan adalah yang dapat diamati dan melibatkan interaksi antara seseorang dan suatu objek atau antara orang dan orang lain. Tugas-tugas kognitif mempunyai beberapa aspek yang dapat diamati tetapi umumnya bersifat mental. Menurut Suwarna (2006) pengajaran dengan metode resitasi tidak hanya dikerjakan dirumah melainkan dapat dikerjakan di laboratorium, di perpustakaan, sekolah, atau di tempat lainnya yang ada hubungannya dengan materi pelajaran yang diberikan. Inilah yang membedakan metode resitasi dengan pekerjaan rumah (PR). Tugas dapat diberikan dalam bentuk daftar sejumlah pertanyaan mengenai mata pelajaran tertentu atau salah satu perintah yang harus dibahas dengan diskusi atau perlu dicari uraiannya pada buku pelajaran.

Ragalin (1996), menyatakan penggunaan metode resitasi yang dapat diberikan dalam kegiatan di laboratorium relevan dengan hakikat IPA yang secara proses menekankan 
Peningkatan Hasil Belajar Ipa Siswa Kelas V Melalui Metode Resitasi Di Sd Al Azhar Syifa Budi Jakarta Selatan

Herlynda Syopyan

siswa beraktivitas dalam kerja laboratorium.. Observasi merupakan langkah metode ilmiah untuk menuntun siswa merumuskan masalah dan pengumpulan data di dalam eksperimen. Menurut Slameto (2010), tugas yang diberikan oleh guru kepada siswa dapat berupa pengerjaan tes/ulangan atau ujian, mengerjakan latihan-latihan yang ada di dalam buku ataupun soal-soal buatan sendiri. Roestiyah (2008) menjelaskan, teknik pemberian tugas atau resitasi biasanya digunakan dengan tujuan agar siswa memiliki hasil belajar yang lebih mantap karena siswasiswa melaksanakan latihan-latihan selama melakukan tugas, sehingga pengalaman siswa dalam mempelajari sesuatu dapat lebih terintegrasi. Pemberian tugas kepada siswa dengan demikian tidak serta merta menggantikan peran guru di dalam mengajar. Sebelum guru memberikan tugas, terlebih dahulu menyampaikan materi pelajaran melalui interaksi timbal balik dengan siswa, baru kemudian siswa melaksanakan tugas yang diberikan oleh guru.

Menurut Surakhmad (2003), tugas yang harus dilakukan oleh siswa harus jelas. Guru dalam memberikan tugas harus menjelaskan aspek-aspek yang perlu dipelajari oleh siswa, agar siswa tidak merasa bingung mengenai apa yang harus dipelajari dan dari segi-segi mana yang harus dipentingkan. Penerapan metode resitasi dalam pembelajaran IPA mencakup tiga langkah yaitu : Fase pemberian tugas dengan mempertimbangkan, tugas yang akan dicapai, jenis tugas yang jelas dan tepat sehingga siswa mengerti apa yang ditugaskan tersebut, sesuai dengan kemampuan siswa, ada petunjuk/sumber yang dapat membantu pekerjaan siswa, dan waktu yang disediakan untuk mengerjakan tugas tersebut harus relevan. Sedangkan fase belajar meliputi diberikan bimbingan pengawasan oleh guru, diberikan dorongan sehingga siswa mau bekerja, diusahakan tugas tersebut dikerjakan oleh siswa sendiri. dianjurkan agar siswa mencatat hasil-hasil yang diperoleh dengan baik dan sistematik, selanjutnya fase melaporkan hasilnya kepada guru dapat berupa laporan siswa baik lisan / tertulis dari apa yang telah dikerjakan, ada Tanya jawab/diskusi kelas, penilaian hasil pekerjaan siswa baik dengan tes maupun non tes atau dengan cara lain.

Menurut Mulyasa (2009), guna mengoptimalkan penerapan metode resitasi dalam proses pembelajaran maka guru perlu memperhatikan langkah-langkah sebagai berikut; tugas harus direncanakan secara jelas dan sistematis terutama tujuan penugasan dan cara pengerjaannya, tugas yang diberikan harus dapat dipahami oleh siswa, kapan mengerjakannya, bagaimana cara 
mengerjakannya, berapa lama harus dikerjakan, secara individu atau kelompok, dan lain-lain.

Kelebihan metode resitasi yang dikemukakan oleh Moeslichatoen (2004), memberikan pengalaman belajar yang dapat meningkatkan cara belajar yang lebih baik dan memantapkan penguasaan perolehan hasil belajar. Pemberian tugas apabila dirancang secara tepat dan proporsional akan dapat meningkatkan bagaimana cara belajar yang benar. Menurut Djamarah dan Zain (2006), kelebihan metode resitasi di dalam proses pembelajaran dibandingkan metode lain, antara lain, lebih merangsang siswa dalam melakukan aktivitas belajar individual atau kelompok; dapat mengembangkan kemandirian siswa di luar pengawasan guru, dapat membina tanggung jawab dan disiplin siswa; dan dapat mengembangkan kreatifitas siswa.

Disamping kelebihan-kelebihan penerapan metode resitasi juga terdapat beberapa kelemahan, antara lain : siswa sulit dikontrol, apakah benar ia yang mengerjakan tugas ataukah orang lain; khusus untuk tugas kelompok, tidak jarang yang aktif mengerjakan dan menyelesaikannya adalah anggota tertentu saja sedangkan anggota lainnya tidak berpartisipasi dengan baik; tidak mudah memberikan tugas yang sesuai dengan perbedaan individu siswa; dan sering memberikan tugas yang monoton (tidak bervariasi) dapat menimbulkan kebosanan siswa.

Berdasarkan uraian diatas maka dapat disimpulkan bahwa metode resitasi atau penugasan adalah metode penyajian bahan oleh guru dan kemudian guru memberikan tugas tertentu agar siswa aktif dalam pembelajaran dan memberikan bimbingan dalam menyelesaikan tugas serta mengevaluasi siswa dalam mempertanggungjawabkan tugas tersebut.

Menurut Kartono ( 2007), perkembangan daya ingatan anak kelas V SD sudah memasuki masa sekolah Dasar 6 -12 tahun (periode intelektual), dalam keadaan normal pikiran anak usia Sekolah Dasar berkembang secara berangsur-angsur dan secara tenang. Disamping keluarga, sekolah, memberikan pengaruh yang sistematis terhadap pembentukan akal budi anak. Ingatan anak pada usia 6 - 12 tahun ini mencapai intensitas yang paling kuat. Menurut Piaget menjelaskan bahwa anak usia 7 - 11 tahun masuk ke dalam tahapan operasional konkret. Pada tahapan ini, pemikiran intuitif asalkan pemikiran tersebut dapat diaplikasikan menjadi contoh-contoh yang konkret dan spesifik. Anak pada tahapan ini dapat menunjukkan operasi-operasi konkret yang merupakan tindakan mental 2 arah (reversible) terhadap objek-objek ini dan konkret. Makmun (2009) menyatakan bahwa 
Peningkatan Hasil Belajar Ipa Siswa Kelas V Melalui Metode Resitasi Di Sd Al Azhar Syifa Budi Jakarta Selatan

Herlynda Syopyan

anak usia $7-12$ tahun memiliki prilaku kognitif yang tampak berupa kemampuannya dalam proses berpikir untuk mengoperasikan kaidah-kaidah logika meskipun masih terikat dengan objek-objek yang bersifat konkret.

Penelitian yang dilaporkan Kusdinah (1990),menyimpulkan prestasi belajar IPS sejarah siswa yang diajar dengan metode resitasi lebih baik dari pada yang diajarkan dengan metode ceramah-diskusi. Penelitian yang dilakukan oleh Iryanti (2008) menyimpulkan bahwa pembelajaran yang dilakukan oleh guru Biologi dengan menggunakan metode resitasi bebas, berhasil meningkatkan motivasi belajar biologi siswa kelas X5 sampai 71,88\%. Selain itu, pembelajaran yang dilakukan oleh guru Biologi dengan menggunakan metode resitasi bebas, berhasil meningkatkan hasil belajar Biologi siswa X5 di atas KKM klasikal sebesar $87.50 \%$. Dan Penelitian Kusdiati (2010) menyimpulkan metode resitasi dapat meningkatkan hasil belajar IPA sebesar 89,18\%. Thomas E. W. Elliot (1983), meneliti 100 siswa SLTA di Afrika yang mempelajari matematika dengan menggunakan metode resitasi, hasilnya skor hasil belajar dengan menggunakan metode resitasi adalah 72 . Meskipun tidak dijelaskan skor hasil belajar dengan metode yang lain, tetapi secara tegas dikemukakan bahwa dengan metode resitasi hasil belajar lebih baik.

Ada berbagai metode pembelajaran yang dapat dilakukan guru antara lain metode ceramah, diskusi, tanya jawab, eksperimen, demontrasi, bermain peran, kerja kelompok dan karya wisata. Salah satu metode pembelajaran, yakni metode resitasi yang merupakan metode pembelajaran yang menuntut keaktifan siswa dalam belajar dengan menyelesaikan tugas-tugas yang diberikan guru serta dapat dipertanggungjawabkan oleh siswa, diharapkan mampu untuk meningkatkan hasil belajar siswa khususnya dalam pembelajaran IPA. Untuk itu guru merasa perlu diadakan penelitian tindakan untuk meningkatkan hasil belajar serta keaktifan siswa dengan melaksanakan penelitian tindakan kelas.

Trianto (2011) dalam bukunya penelitian tindakan pertama kali diperkenalkan oleh ahli psikologi Kurt Lewin pada tahun 1946, yang selanjutnya dikembangkan oleh Stephen Kemmis, Robin Mc Taggart, John Elliot, Dave Ebbutt dan lainnya. Manurung (2008), penelitian tindakan adalah metode penelitian yang menekankan pada praktek sosial, bertujuan ke arah peningkatan, sebuah proses siklus, diikuti oleh penemuan yang sistematis, sebuah proses reflektif, bersifat partisipatif, dan ditentukan oleh pelaksana. Dalam sumber 
lain, Kemmis (1983) didalam Rochiati (2009), menjelaskan bahwa penelitian tindakan adalah sebuah bentuk inkuiri reflektif yang dilakukan secara kemitraan mengenai situasi sosial tertentu (termasuk pendidikan) untuk meningkatkan rasionalitas dan keadilan dari :

a) Kegiatan praktek sosial atau pendidikan mereka, b) Pemahaman mereka mengenai kegiatan-kegiatan praktek pendidikan ini, dan c) Situasi yang memungkinkan terlaksananya kegiatan praktek ini.

Menurut Trianto (2011), penelitian tindakan kelas merupakan suatu penelitian kualitatif yang dilakukan oleh guru sendiri ketika mendapatkan permasalahan dalam pembelajaran dan mencarikan solusinya dalam upaya memperbaiki kualitas pembelajarannya. Menurut Aqib ( 2006), pada dasarnya penelitian tindakan kelas merupakan salah satu cara yang strategis bagi guru untuk memperbaiki layanan kependidikan yang harus diselenggarakan dalam konteks pembelajaran di kelas. Menurut Wijaya (2004), sebelum penelitian dimulai sebaiknya disusun terlebih dahulu rencana secara tertulis apa-apa saja yang akan dilakukan, mengapa hal tersebut dilakukan, kepada siapa melakukannya, alat dan bahan apa saja yang diperlukan, berapa biayanya, dan apa hasilnya yang dapat harus diperoleh. Semua itu disusun menjadi sebuah dokumen yang dapat digunakan sebagai pedoman dalam pelaksanaan penelitian. penelitian tindakan kelas merupakan proses yang dilakukan oleh praktisi berusaha untuk mempelajari masalah yang ditemuinya dalam melaksanakan tugas secara ilmiah untuk pembimbingan, memperbaiki, mengevaluasi keputusan dan tindakannya.

Berdasarkan acuan teori rancangan intervensi tindakan sebagaimana diuraikan, maka rumusan hipotesis penelitian tindakan ini adalah Metode Resitasi dapat meningkatkan hasil belajar IPA siswa kelas V SD Al Azhar Syifa Budi Jakarta Selatan pada pokok pembahasan Penyesuaian Makhluk Hidup.

\section{METODE}

Tujuan penelitian ini adalah untuk meningkatkan kualitas pembelajaran di kelas, dan secara khusus bertujuan untuk mengetahui penerapan metode resitasi dapat meningkatkan hasil belajar siswa SD Al Azhar Syifa Budi Jakarta Selatan, pada pokok pembahasan "Penyesuaian Makhluk Hidup". Subjek penelitiannya adalah siswa Kelas V SD Al Azhar Syifa Budi semester genap Tahun Pelajaran 2011/2012 yang berjumlah 22 siswa, 13 laki-laki dan 9 perempuan. Penelitian ini dilakukan selama 1 bulan yaitu pada bulan Mei 2012.

Pada tiap siklus rancangan action research meliputi empat tahapan yaitu : merumuskan masalah dan merencanakan tindakan (plan); (2) melaksanakan tindakan dan pengamatan (act \& observe); (3) refleksi 
Peningkatan Hasil Belajar Ipa Siswa Kelas V Melalui Metode Resitasi Di Sd Al Azhar Syifa Budi Jakarta Selatan

Herlynda Syopyan

hasil pengamatan (reflect), dan (4) perubahan atau revisi perencanaan untuk pengembangan selanjutnya (plan revised). Metode Action Research yang digunakan dalam penelitian ini dikembangkan oleh Kemmis \& Taggart, seperti pada Gambar berikut :(1) Perencanaan (Planning), (2) Pelaksanaan (Acting),

Observasi (Observing),

(4) Refleksi (Reflecting).

Konteks dalam penelitian ini, keempat tahapan penelitian tindakan kelas di atas distrukturisasi kedalam kegiatan yang dimulai dari pembelajaran siklus I satu sampai siklus II. Pencapaian hasil belajar siklus I belum memenuhi kriteria ketuntasan minimal (KKM) dengan nilai 70 yang diterapkan maka dilanjukan ke pembelajaran siklus II, sehingga diperoleh hasil belajar yang sesuai dengan KKM yang diharapkan. Proses pembelajaran setiap siklus meliputi: perencanaan, pelaksanaan tindakan, refleksi, dan revisi tindakan. Subjek penelitian ini adalah siswa SD Al Azhar Syifa Budi Jakarta Selatan semester genap, tahun Pelajaran 2011/2012. Rancangan tindakan dalam setiap siklus pembelajaran meliputi empat tahap tahapan yaitu; perencanaan, pelaksanaan, refleksi tindakan, revisi perencanaan tindakan. Peneliti membuat rencana pembelajaran yang akan digunakan dalam proses pembelajaran. Rencana pembelajaran (RP) yang dibuat mengkaitkan mata pelajaran sesuai dengan fokus penelitian ini dan menggunakan metode resitasi, guna meningkatkan hasil belajar IPA.

Untuk memperoleh gambaran kesesuaian antara perencanaan tindakan dengan pelaksanaannya maka dalam proses pembelajaran dilakukan pengamatan / monitoring yang dilakukan observer sebanyak dua orang. Pada pelaksanaan tindakan sebelum pembelajaran Siklus I berlangsung, siswa diberikan tes awal. Selama pembelajaran Siklus I (pertemuan 1, 2, dan 3) dilakukan monitoring oleh observer terutama berkaitan dengan keterlaksanaan disain pembelajaran, kejelasan disain, suasana kelas, kesulitan siswa dalam melaksanakan kegiatan, penguasaan konsep oleh siswa, dan aktivitasnya dalam proses pembelajaran IPA.

Alat monitoring yang disiapkan yakni: lembar observasi dan daftar cek. Pada tiap-tiap pertemuan pembelajaran, peneliti melakukan diskusi dengan pengamat sebagai upaya kolaborasi untuk membahas kelemahankelemahan dari metode pembelajaran resitasi yang diterapkan dalam penelitian ini. Berdasarkan temuan-temuan implementasi tindakan, hasil monitoring, dan refleksi maka digunakan untuk memperbaiki rencana pembelajaran dengan metode resitasi pada Siklus II. Apabila hasil pembelajaran Siklus I belum maksimal maka dilanjutkan Siklus II. 
Pembelajaran Siklus II adalah sebagai upaya perbaikan skenario disain pembelajaran yang baru.

Untuk mengetahui siswa telah menguasai materi " Penyesuaian Makhluk Hidup" dilakukan pengukuran hasil belajar melalui tes. Ukuran keberhasilan adalah mastery learning atau belajar tuntas apabila aktivitas guru dan siswa selama pembelajaran dengan metode resitasi meningkat pada setiap siklusnya dan pada siklus terakhir telah tuntas proses pembelajarannya. Hal ini sesuai dengan prinsip belajar tuntas (mastery learning), yaitu proses pembelajaran mencapai 100\%. Selain itu, penelitian ini dianggap berhasil, jika pada akhir siklus terdapat $80 \%$ dari siswa yang ada telah mencapai KKM yang ditetapkan yaitu 70.

Data penelitian ini terdiri atas : 1) aktivitas guru dalam mengajar, 2) aktivitas siswa dalam pembelajaran, dan 3) hasil belajar siswa sebagai pembanding keberhasilan guru dalam mengajar. Sumber data dalam penelitian ini antara lain : 1) guru selama proses pembelajaran dan 2) seluruh siswa kelas $\mathrm{V}$ yang menjadi subjek penelitian pada semester genap Tahun Pelajaran 2011/2012.

Hasil belajar IPA adalah skor yang diperoleh siswa setelah menjawab dengan benar dari sejumlah 20 butir tes pada standar kompetensi "Penyesuaian Makhluk Hidup" yang mencakup indikator sebagai berikut: 1)
Memahami definisi adaptasi dan habitat serta istilah adaptasi pada hewan ; 2) Mengidentifikasi bentuk paruh dan kaki burung berdasarkan jenis makanannya; 3) Membedakan bentuk dan bagian tubuh hewan untuk melindungi dan menyesuaikan diri dengan lingkungannya; 4) Mengidentifikasi penyesuaian hewan untuk menyelamatkan diri dari musuhnya. Kisi-kisi tes hasil belajar IPA pada materi pelajaran "Penyesuaian Makhluk Hidup”, berpedoman kepada kurikulum yang berlaku saat ini yakni Kurikulum Tingkat Satuan Pendidikan (KTSP) untuk menentukan indikator yang diperoleh standar kompetensi. Kisi-kisi yang dikembangkan dalam penyusunan instrumen ini adalah berupa pengukuran hasil belajar menggunakan cara tes tertulis.

\section{HASIL}

Refleksi pembelajaran pada siklus I, merupakan pengkajian terhadap aspek keberhasilan dan kegagalan yang telah tercapai peneliti dalam melakukan tindakan di kelas. Berdasarkan hasil pengamatan yang diperoleh dari tahap observasi proses belajar mengajar melalui pembelajaran pada Siklus I, ternyata hasil yang dicapai belum memuaskan terutama pada aktivitas guru dalam melaksanakan metode resitasi belum optimal (berdasarkan RAG baru mencapai 89,99 \%). Hasil ini mengindikasikan perlunya pembelajaran dengan menggunakan metode resitasi 
Peningkatan Hasil Belajar Ipa Siswa Kelas V Melalui Metode Resitasi Di Sd Al Azhar Syifa Budi Jakarta Selatan

Herlynda Syopyan

dilanjutkan dan ditingkatkan pada siklus berikutnya.

Berdasarkan catatan observer, pelaksanaan metode resitasi yang telah disusun sendiri oleh peneliti menunjukkan bahwa masih terdapat kekurangan yang disebabkan oleh kelalaian, seperti adanya langkah-langkah yang belum lengkap dilakukan. Kelalaian ini menyebabkan metode resitasi yang dilaksanakan oleh peneliti belum mencapai 100\%. Begitu juga dengan aktivitas siswa dalam pembelajaran belum memuaskan. Beberapa siswa tidak aktif dan masih memperlihatkan aktivitas negatif pada saat proses belajar berlangsung.

Selain itu hasil belajar IPA siswa belum mencapai seperti yang diharapkan, karena langkah metode yang direncanakan belum sepenuhnya terlaksana dengan baik. Kegagalan lainnya adalah dari aspek aktivitas siswa selama pembelajaran yang bersifat negatif adalah yaitu siswa mengobrol, berpindah tempat duduk, dan berbicara di luar konteks belajar masih banyak mewarnai pembelajaran pada Siklus I.

Walaupun hasil pengamatan dan refleksi Siklus I menekankan pada kelemahan yang ditemui, namun masih terdapat kemajuan yang berarti yang ditemukan dalam proses pembelajaran. Hal ini terpantau dari hasil belajar siswa melalui metode resitasi yang 
resitasi yang dilaksanakan peneliti dalam pembelajaran IPA di SD Al Azhar Syifa Budi Jakarta Selatan dapat dinyatakan belum berhasil. Proses pembelajaran perlu diperbaiki dengan tindakan Siklus II. Hal ini juga diperkuat bahwa di dalam proses belajar mengajar, masih dijumpai kegagalan terutama dalam pelaksanaan metode resitasi.

Refleksi yang dilakukan pada Siklus I, selanjutnya digunakan untuk perencanaan Siklus II. Refleksi pada pembelajaran Siklus II, merupakan pengkajian terhadap respek keberhasilan dan kegagalan yang telah dicapai peneliti dalam melakukan tindakan di kelas. Berdasarkan hasil pengamatan yang diperoleh dari tahap observasi proses belajar mengajar melalui pembelajaran Siklus II, hasil yang dicapai memuaskan terutama pada kemampuan guru dalam melaksanakan metode resitasi, sudah lengkap dan terlaksana yaitu secara nilai mutu mencapai $100 \%$. Hasil ini mengindikasikan peneliti telah memperbaiki pelaksanaan metode pembelajarannya yaitu metode resitasi secara lengkap.

Berdasarkan catatan observer, pelaksanaan metode resitasi oleh peneliti menunjukkan perbaikan terhadap kekurangan dan kelalaian seperti yang terdapat langkahlangkah metode resitasi pada Siklus I, menjadi lebih lengkap. Perbaikan kelalaian ini menghasilkan metode resitasi yang dilaksanakan peneliti sudah mencapai 100\%.
Sesuai dengan ketentuan dari intervensi tindakan yang diharapkan, maka tindakan penelitian dengan menggunakan metode resitasi, untuk meningkatkan hasil belajar IPA, pada Siklus II sudah mencapai mastery learning (100\%), sehingga tindakan tidak dilanjutkan lagi pada siklus selanjutnya.

Pada proses pembelajaran melalui metode resitasi, tampak bahwa kualitas pembelajaran yang ditampilkan oleh guru dan siswa sudah memuaskan. Kegiatan pembelajaran telah sesuai dengan langkah-langkah pembelajaran dengan menggunakan metode resitasi, yang telah didesain oleh peneliti. Selain itu telah terjadi peningkatan hasil belajar IPA. Siswa tampak antusias, senang dan mengatakan bahwa proses pembelajaran yang dilakukan menyenangkan dan membuat mereka merasa aktif dan lebih memahami materi yang diberikan.

Hasil belajar yang diperoleh setelah proses pembelajaran (mastery learning) pada Siklus II sebesar 90,90\% sudah mencapai KKM yang ditetapkan, yaitu $80 \%$. Hasil ini dapat diinterpretasikan bahwa hasil belajar siswa dibandingkan dengan sebelum tindakan, mengalami peningkatan yang besar. Demikian pula dari aspek pencapaian KKM. Pada kondisi sebelum tindakan, siswa yang memperoleh nilai sama dengan atau lebih besar dari KKM baru mencapai $50 \%$. Sedangkan setelah tindakan pencapaian KKM 
Peningkatan Hasil Belajar Ipa Siswa Kelas V Melalui Metode Resitasi Di Sd Al Azhar Syifa Budi Jakarta Selatan

Herlynda Syopyan

sebesar 90,90\%. Pencapaian ini telah melampaui target KKM klasikal yang diharapkan. Hal ini dapat disebabkan oleh konsintesi guru dalam mengajar sesuai metode resitasi yang telah direncanakan dan juga disebabkan oleh aktivitas negatif siswa (mengobrol, berpindah tempat, dan berbicara diluar konteks pembelajaran) yang sudah jauh berkurang, sehingga kesadaran dan tanggung jawab mereka dalam belajar dan mengerjakan tugas-tugas yang diberikan sudah mulai tampak.

\section{PEMBAHASAN}

Analisis data yang dapat dikemukakan dalam penelitian ini, memfokuskan pada hasil belajar dan aktivitas siswa selama pembelajaran berlangsung. Kedua fokus analisis tersebut membandingkan kondisi antara Siklus I dan Siklus II. Pertama, hasil belajar. Berdasarkan data hasil tindakan Siklus I dan Siklus II, pencapaian KKM keduanya dirangkum dalam tabel berikut ini.

Tabel 1 : Rangkuman Pencapaian KKM pada Kompetensi Dasar Penyesuaian Makhluk Hidup terhadap Lingkungannya.

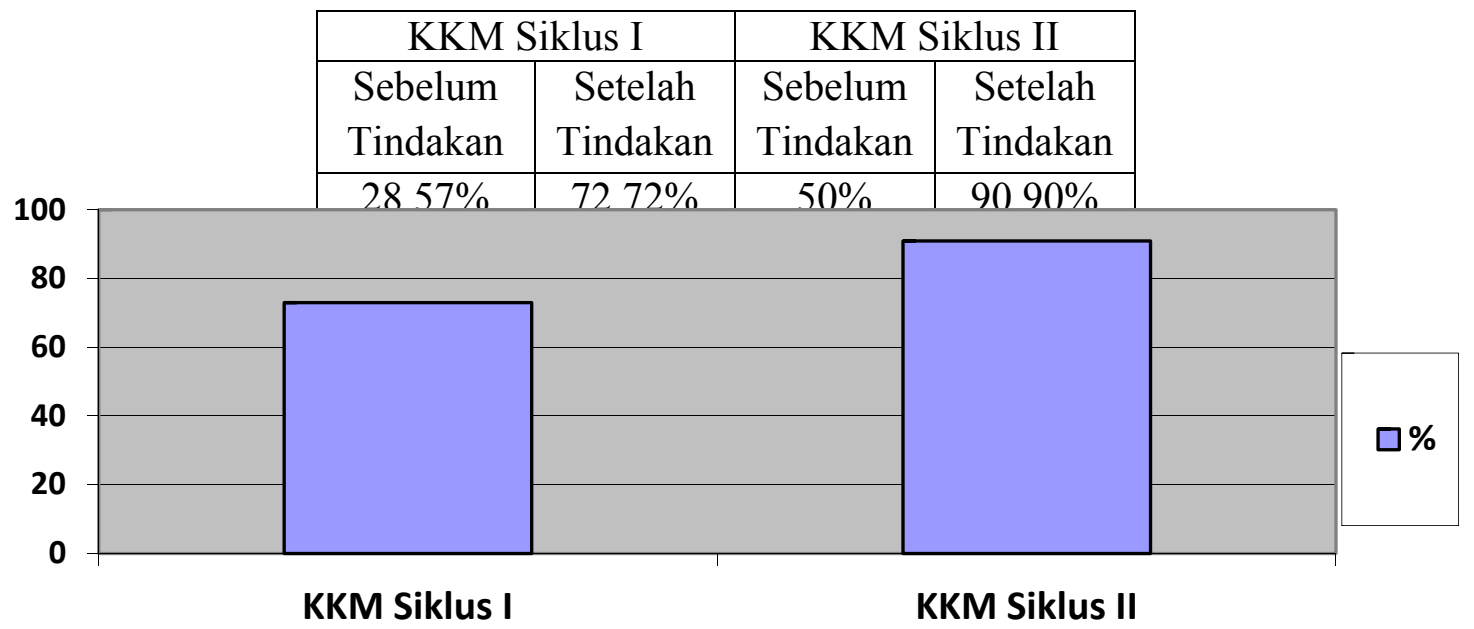

Gambar 1 : Perbandingan KKM Siklus I dan KKM Siklus II

Perbandingan pencapaian KKM ditetapkan sebesar 80\%. Seiring dengan pelajaran IPA pada rangkuman data KKM di perbaikan pelaksanaan Siklus II yakni atas menunjukkan bahwa pada Siklus I, memperbaiki pelaksanaan metode resitasi penerapan metode resitasi belum berhasil secara lengkap maka KKM yang ditetapkan memenuhi harapan KKM klasikal yang sebesar 80\%, dapat dilampaui. Pada Siklus II 
berhasil dicapai KKM sebesar 90,90\%. Peningkatan KKM pada Siklus II ini menjadi indikasi bahwa perbaikan terhadap pelaksanaan metode mengajar guru, berhubungan dengan hasil belajar siswa.

Interpretasi hasil analisis dilakukan setelah dilakukan analisis data. Interpretasi hasil analisis dimaksudkan untuk membandingkan hasil analisis pada siklus I dan siklus II, melihat hubungan yang terjadi antara kedua siklus selama pelaksanaan tindakan, menafsirkan hasil analisis data pada siklus I dan siklus II, dan memperluas analisis dan implikasi hasil penelitian yang dilakukan. Dari perbandingan hasil belajar siswa dari Siklus I dan Siklus II, maka dapat di presentasikan bahwa peningkatan telah terjadi pada setiap siklus. Hal ini digambarkan dari pola kenaikan nilai siswa antar siklus yang mengalami peningkatan dan saling berkorelasi.

\section{SIMPULAN}

Berdasarkan hasil penelitian dan pembahasan yang telah dilakukan maka dapat disimpulkan bahwa:

1) Penggunaan metode resitasi dapat meningkatkan hasil belajar IPA siswa kelas 5 SD Al Azhar Syifa Budi Jakarta pada standar kompetensi "Mengidentifikasi cara makhluk hidup menyesuaikan diri dengan lingkungannya".

2) Terdapat hubungan antara keberhasilan pembelajaran dengan langkah-langkah operasional pembelajaran, yang dirancang dalam penelitian tindakan kelas yang dilakukan peneliti.

\section{DAFTAR RUJUKAN}

Arikunto, Suharsimi. 2006. Dasar-dasar Evaluasi Pendidikan. Bumi Aksara, Jakarta

Arikunto,dan Jabar Cepi S.A. 2010. Evaluasi Program Pendidikan . (Edisi kedua) Bumi Aksara, Jakarta.

Arthur A. Carin dan Robert B Sund. 1989.Teaching Science Through Discovery Colombus, Ohio: Merrill Publishing Company

Bloom Benjamin S, (ed). 1996. Taxonomy of Educational Objection, Handbook I: Cognitive Domain, New York:

Bruce Joyce, Marsya Weil, and Emil Calhoun, 2009. Models of Teaching.Boston: Pearson Education, Inc

Kember David, 2000. Action Learning and Action Research Improving the Quality of Teaching London: Kogan Page Limited.

Djamarah dan Aswan Zain, 2006. Strategi Belajar Mengajar . (Jakarta: Rineka Cipta

E. Mulyasa, 2009. Menjadi Guru Profesional, Menciptakan Pembelajaran Kreatif dan Menyenangkan.

Bandung:PT Rosdakarya

Heinz Kook, 1992. Saya Guru Yang Baik?. Yogyakarta: Kanisius.

http://duniabaca.com/pengertian-belajar-danhasil-belajar.html

http://www.bpkpenabur.or.id/files/09 0.pdf (diakses 30 April 2012)

I. M. A Mariana, 1995. Hakikat Pendekatan Science, Technology, and Society 
Jakarta: Direktorat Pendidikan Guru dan Teknis, Depdikbud.

Kartini Kartono, 2007. Psikologi Anak Jakarta : Mandar Maju,

Komnas Indonesia untuk Unesco, Dunia Belajar. Terjemahan.W.P. Napitupulu Depdikbud, Jakarta.1999.

Kusdianti, Peningkatan Hasil Belajar IPA Melalui Metode Resitasi di SMP Negeri 281 Jakarta Tahun Pelajaran 20092010, Tesis. Jakarta : Pendidikan Dasar Pascasarjana UNJ, 2010.

Lorin W. Anderson and David R. Krathwohl, Taxonomy for Learning, Teaching, and assessing : A Revision Of Bloom's Taxonomy of Educational objectives, (New York: Addision Wesley Longman, Inc, 2001).

M. Manurung 2008. Penelitian Tindakan Kelas, Jakarta : Gramedia Widiasarana Indonesia,

Makmun. Abin Syamsuddin, 2009. Psikologi Pendidikan, Bandung : Rosdakarya

Maman Wijaya, 2004. Penelitian Tindakan Kelas.Bandung: Pusat Pengembangan Penataran Guru (P3G) IPA, Ditjen Dikdasmen, Depdiknas

Maman Wijaya. 2004. Penelitian Tindakan Kelas.Bandung: Pusat Pengembangan Penataran Guru (P3G) IPA, Ditjen Dikdasmen, Depdiknas

Muhibin Syah, 2010. Psikologi Pendidikan Suatu Pendekatan Baru. Bandung: Rosdakarya

Nana Sudjana, 1990.Teori-teori Belajar untuk Pengajaran. Jakarta: FE UI.

Oemar Hamalik, 2009. Perencanaan Pengajaran Berdasarkan Pendekatan Sistem. Jakarta: Bumi Aksara.
Peningkatan Hasil Belajar Ipa Siswa Kelas V Melalui Metode Resitasi Di Sd Al Azhar Syifa Budi Jakarta Selatan

Herlynda Syopyan

R. Moeslichatoen, 2004. Metode Pengajaran di Taman Kanak-kanak .Jakarta: Kerjasama Departemen Pendidikan dan Kebudayaan dengan Rineka Cipta.

Rita Iryanti, Upaya Peningkatan Motivasi Belajar dan Hasil Belajar Biologi melalui Metode Resitasi Bebas Siswa Kelas X SMA Negeri I Metro Tahun Pelajaran 2008/2009. Metro: SMA Negeri I Metro.

Roestiyah N.K., 2008. Strategi Belajar Mengajar. Jakarta: Rineka Cipta

Roger R. Ragalin, 1985. Health Biology. Lexington: D.C Heath and Company,

Semiawan C, et.al. 1989. Pendekatan Keterampilan Proses. Jakarta: Gramedia

Slameto, 2010. Belajar dan faktor-faktor yang mempengaruhinya. Jakarta:Rineka Cipta

Sri Kusdinah,1990."Studi Keefektifan Metode Resitasi dan Diskusi terhadap Prestasi Belajar IPS Sejarah Ditinjau dari Tingkat Kesadaran Sejarahnya (Suatu Eksperimen pada SMP Swasta di Kota Madya Surakarta 1988/1989", Tesis. Jakarta: Fakultas Pascasarjana IKIP Jakarta

Suwarna, et al., 2006. Pengajaran Mikro, Pendekatan Praktis Dalam menyiapkan Pendidik Profesional. Tiara Wacana, Yogyakarta.

Syaodih Sukmadinata Nana, 2005. Landasan Psikologi Proses Pendidikan. PT Remaja Rosdakarya.

Trianto, 2010. Panduan lengkap Penelitian Tindakan Kelas. Jakarta: Prestasi Pustakaraya.

T. Sarkim. 1998. "Humaniora dan Pembelajaran Sains" dalam Sumaji dkk, Pendidikan Sains yang Humanistis. Yogyakarta: Kanisius, 
JURNAL PENDIDIKAN DASAR

Volume 6 Edisi 1 Mei 2015

Thomas E.W. Elliot, Mathematic International Journal of educational Development, Volume 7, 1983.

Wina Sanjaya, Strategi Pembelajaran Berorientasi Standar Proses Pendidikan. Jakarta: Kencana Prenada Media Group, 2006.

Winarno Surachmad, Pengantar Interaksi Mengajar Belajar. Bandung :Tarsito. 2003.

W.S. Winkel, Psikologi Pendidikan dan Evaluasi Belajar. Jakarta : Gramedia, 1983.

Zainal Aqib, Penelitian Tindakan Kelas Untuk Guru. Bandung : Yrama Widya, 2006. 